Journal of Maternal and Child Health (2018), 3(4): 252-260

https://doi.org/10.26911/thejmch.2018.03.04.02

\title{
Factors Associated with Use of Intra-Uterine Device in Women of Reproductive Age in Boyolali, Central Java
}

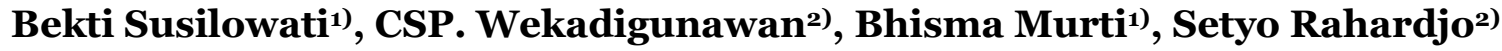 \\ 1)Masters Program in Public Health, Universitas Sebelas Maret \\ ${ }^{2)}$ Faculty of Medicine, Universitas Sebelas Maret
}

\begin{abstract}
Background: Family planning is a key strategy for reduction of maternal mortality. Family planning aims to control birth in order to control population growth. Long-acting reversible contraceptives (LARCs), which include intra-uterine device (IUD), are the most effective methods of birth control. Studies into factors affecting the uptake of IUD was lacking in Indonesia. This study aimed to investigate factors associated with use of IUD in women of reproductive age in Boyolali, Central Java, using multilevel analysis model and Theory of Planned Behavior.

Subjects and Method: This was a case control study carried out in 25 posyandus (integrated community health posts) in Boyolali, Central Java, from April to June 2018. A sample of 200 women was selected by simple random sampling. The dependent variable was IUD use. The independent variables were education, family income, intention, attitude, subjective norm, perceived behaviour control, and husband support. The data were collected by questionnaire and analyzed by a multilevel logistic regression on Stata 13 .

Results: IUD use among women reproductive age increased with higher maternal education $(b=$ 4.06; $95 \% \mathrm{CI}=0.68$ to $7.44 ; \mathrm{p}=0.019)$, higher family income $(\mathrm{b}=3.90 ; 95 \% \mathrm{CI}=1.67$ to 7.64 ; $\mathrm{p}=0.041)$, positive attitude $(\mathrm{b}=4.54 ; 95 \% \mathrm{CI}=0.52$ to $8.55 ; \mathrm{p}=0.027)$, positive subjective norm $(\mathrm{b}=$ 3.06; 95\% CI $=0.01$ to 6.10; $\mathrm{p}=0.049)$, strong perceived behaviour control $(\mathrm{b}=3.40 ; 95 \% \mathrm{CI}=-$ 0.04to 6.85; $\mathrm{p}=0.053)$, strong intention $(\mathrm{b}=3.18 ; 95 \% \mathrm{CI}=-0.06$ to $6.41 ; \mathrm{p}=0.054)$, and strong husband support $(\mathrm{b}=4.28 ; 95 \% \mathrm{CI}=0.01$ to $7.44 ; \mathrm{p}=0.050)$. Posyandu had a contextual effect on IUD use with $\mathrm{ICC}=32.10 \%$.

Conclusion: IUD use among women reproductive age increases with higher maternal education, higher family income, positive attitude, positive subjective norm, strong perceived behaviour control, strong intention, and strong husband support. Posyandu has sizeable contextual effect on IUD use.
\end{abstract}

Keywords: intra-uterine device, utilization, determinants, multilevel analysis

\section{Correspondence:}

Bekti Susilowati. Masters Program in Public Health, Universitas Sebelas Maret, Jl. Ir. Sutami No. 36 A, Surakarta, Central Java. Email: susila.nawa16@gmail.com. Mobile: +6281226808595

\section{BACKGROUND}

Indonesia is a developing country that cannot be separated from the problem of population. The problem faced is the increase of population number. The population of Indonesia reached 258,704,986 people, with population growth rate of 3.24 million per year (Central Bureau of Statistics, 2016). An effort by the government to control the rate of population growth is to implement Family Planning (KB) program (Ministry of Health, 2016).

Data of National Population and Family Planning Agency (BKKBN) show that in 2016, the number of active $\mathrm{KB}$ participants towards fertile couples in Indonesia is $74.8 \%$. The details of active family planning participants on infertile couples were injectable contraception (47.96\%), pills (22.81\%), implant (11.20\%), IUD (10.61\%), Condom (3.23\%), tubectomy 
(3.54\%), vasectomy (0.64\%). The highest use of contraception is injection of $47.97 \%$ and the use of IUD is still low i.e. $10.61 \%$ (BKKBN, 2017).

Contraceptive method that meet the effective and efficient elements are contraceptive method of intrauterine device (IUD), female operational method (tubectomy), male operational method (vasectomy), and implant. It can called Longacting reversible contraceptives (LARC) (Budiartiet al., 2017).

Long-acting reversible contraceptives (LARC) is an effective, safe and convenient contraceptive choice and the most commonly used reversible contraceptive method in the world with the use of approximately 100 million women, mostly in Nigeria and Kenya (Adeyemiet al., 2016; Njeru, 2010). LARCs have more than 99\% effectiveness in preventing pregnancy in use within one year or more (Glasier and Gebbie, 2012).

Central Java is one of the provinces with relatively high family planning participants. The number of child bearing age couples in 2015 is $6,736,249$. As many as $78.20 \%$ peoples were active contraceptive participants. Central Java Province most common use of contraception is injection (56.2\%), pill (14.1\%), IUD (9.0\%), tubectomy (0.9\%), vasectomy (5.3\%), implant (12.0\%), and condom (2.4 5\%). The most common method of contraception used by active contraceptive participants is an injection (56.2\%), while the contraceptive least selected by active contraceptive participants is tubectomy (0.9\%). It suggests that male participation in family planning is still very low and the limited choice of contraception available to men (Central Java Health Profile 2015).

Boyolali district is one of the areas in Central Java with the number of fertile age of 176,505 . The number of active contra- ceptive participant in Boyolali District in 2014 was $13.6 \%$ and the number of new contaceptive participant was $15.1 \%$. In 2015, IUD use was about $17.7 \%$ and the number of new contaceptive participants was $11.5 \%$. It shows that IUD active participant has an increase of $4.1 \%$.

In 2014 the number of drop out of contraceptive use reached $15.02 \%$. Drop out case Boyolali District is still high because use of non LARCs also high (Health Profile of Boyolali District, 2015).

Couples of childbearing age in Boyolali Regency in 2017 were 177,813. Based on data on Boyolali Health Office, it was recorded $(136,712)$ active $\mathrm{KB}$ participants comprising condom $(1,374)$, pill $(5,063)$, injection $(85,036)$, IUD $(19,020)$, implant $(18,737)$, tubectomy $(6,553)$, and vasectomy (929).

This study aimed to analyze the association between education, family income, attitude, subjective norm, percepsikendali behavior, intention, and husband support on IUD use in Boyolali, Central Java.

\section{SUBJECTS AND METHOD \\ 1. Study Design \\ This was an analytic observational study with a case control design. The study was conducted in 25 posyandus (integrated health posts) in Boyolali, Central Java, from April to June 2018.}

\section{Population and Sample}

The population of this study was women at reproductive age. A sample of 200 women was selected for this study by simple random sampling.

\section{Study Variables}

The dependent variable was IUD use. The independent variables were education, family income, attitude, subjective norm, perceived behavior control, intention, and husband support. 
Journal of Maternal and Child Health (2018), 3(4): 252-260

https://doi.org/10.26911/thejmch.2018.03.04.02

\section{Operational Definition of Variable}

Maternal education was defined as the last formal education level that is taken by the mother to get a diploma. The data were collected by questionnaire. The measurement scale was categorical.

Family income was defined as the average income during the last 6 months as a result of cumulative economic resources of the family members. The data were collected by questionnaire. The measurement scale was continuous.

Attitude was defined as the response of a positive or negative response to the use of IUD. The data were collected by questionnaire. The measurement scale was continuous.

The subjective norm was defined as a person's perception of social pressure to perform or not to engage in a behavior in the form of IUD use. The data were collected by questionnaire. The measurement scale was continuous.

The perception of behavior control was defined as a perception that describes self-efficacy in performing a behavior of IUD use. The data were collected by questionnaire. The measurement scale was continuous.

Intention was defined as the seriousness of the subjects to perform the act or bring up a behavior to use the IUD. The data were collected by questionnaire. The measurement scale was continuous.

Husband support was defined as the various motivations or support given by the husband to the wife either in the form of financial, emotional, and material support for the selection of IUD contraception. The data were collected by questionnaire. The measurement scale was continuous.

\section{Data Analysis}

Univariate analysis was conducted to see the frequency distribution and percentage characteristics of study subjects. Bivariate analysis was done to examine the relationship between IUD use and the independent variable using chi-square test and odds ratio calculation (OR) with confidence level (CI) of $95 \%$. Multivariate analysis used multilevel logistic regression run on Stata 13.

\section{Research Ethics}

The research ethics include informed consent, anonymity, confidentiality and ethical clearance. The ethical clearance in this study was conducted in Dr. Moewardi hospital, Surakarta.

\section{RESULTS}

\section{Subject Characteristics}

The subjects of this study were 200 women of childbearing age, 100 women who use IUD and 100 women who do not use IUD. The frequency distribution of study subject characteristics is described in Table 1.

Table 1 shows that the proportion of Muslim religion is 178 (89.0\%). Half of the study subjects were aged $\geq 27$ years (102, 51.0\%), <senior high school (104, 52.0\%), high family income $(105,52.5 \%)$, and had positive attitude (104, 51.0\%). As many as 101 women (50.5\%) had positive subjective norm, strong perceived behavior control (109, 54.5\%), strong intention (112, 56.0\%), and weak husband (107, 53.5\%).

\section{Bivariate analysis on the IUD use determinants}

Table 2 shows the relationship between maternal education, family income, attitudes, subjective norms, perceived behavior control, intention, husband support, and IUD use. 
Table1. Characteristics of Study Subjects

\begin{tabular}{|c|c|c|}
\hline Variables & Frequency (n) & Percentage (\%) \\
\hline \multicolumn{3}{|l|}{ Religion } \\
\hline $\begin{array}{l}\text { Christian, Catholic, Hinduish, Budhish, and } \\
\text { Konghucu }\end{array}$ & 22 & 11.0 \\
\hline Moslem & 178 & 89.0 \\
\hline \multicolumn{3}{|l|}{ Age } \\
\hline$<27$ years old & 98 & 49.0 \\
\hline$\geq 27$ years old & 102 & 51.0 \\
\hline \multicolumn{3}{|l|}{ Education } \\
\hline$<$ senior high school & 104 & 52.0 \\
\hline$\geq$ senior high school & 96 & 48.0 \\
\hline \multicolumn{3}{|l|}{ Family Income } \\
\hline Low $(<\operatorname{Rp} 1,700,000)$ & 95 & 47.5 \\
\hline \multicolumn{3}{|l|}{ Attitude } \\
\hline Weak & 96 & 48.0 \\
\hline Strong & 104 & 51.0 \\
\hline \multicolumn{3}{|l|}{ Subjective Norm } \\
\hline Negative & 99 & 49.5 \\
\hline Positive & 101 & 50.5 \\
\hline \multicolumn{3}{|l|}{ Perceived control behavior } \\
\hline Low & 91 & 45.5 \\
\hline High & 109 & 54.5 \\
\hline \multicolumn{3}{|l|}{ Intention } \\
\hline Low & 88 & 44.0 \\
\hline High & 112 & 56.0 \\
\hline \multicolumn{3}{|l|}{ Husband Support } \\
\hline Weak & 107 & 53.5 \\
\hline Strong & 93 & 46.5 \\
\hline
\end{tabular}

Table 2. Bivariate analysis on the determinants of IUD use

\begin{tabular}{|c|c|c|c|c|c|c|c|c|c|}
\hline \multirow{3}{*}{ Independent Variables } & \multicolumn{4}{|c|}{ IUD use } & \multirow{2}{*}{\multicolumn{2}{|c|}{ Total }} & \multirow{3}{*}{ OR } & \multirow{3}{*}{$95 \%$ CI } & \multirow{3}{*}{$\mathbf{p}$} \\
\hline & \multicolumn{2}{|c|}{ No } & \multicolumn{2}{|c|}{ Yes } & & & & & \\
\hline & $\mathbf{n}$ & \% & $\mathbf{n}$ & $\%$ & $\mathbf{N}$ & $\%$ & & & \\
\hline \multicolumn{10}{|l|}{ Education } \\
\hline Low (<senior high school) & 84 & 80.8 & 20 & 19.2 & 104 & 100 & \multirow[t]{3}{*}{15.0} & $7 \cdot 55-$ & \multirow{2}{*}{$<0.001$} \\
\hline High ( $\geq$ senior high school) & 21 & 21.9 & 75 & 78.1 & 96 & 100 & & 29.82 & \\
\hline \multicolumn{9}{|l|}{ Family Income } & \\
\hline Low & 78 & 82.1 & 17 & 17.9 & 95 & 100 & \multirow[t]{3}{*}{$13 \cdot 3$} & $6.69-$ & \multirow{3}{*}{$<0.001$} \\
\hline High & 27 & 25.7 & 78 & 74.3 & 105 & 100 & & 26.25 & \\
\hline \multicolumn{8}{|l|}{ Attitude } & & \\
\hline Weak & 86 & 89.6 & 10 & 10.4 & 96 & 100 & \multirow[t]{3}{*}{38.5} & $16.91-$ & \multirow{2}{*}{$<0.001$} \\
\hline Strong & 19 & 18.3 & 85 & 81.7 & 104 & 100 & & 87.56 & \\
\hline \multicolumn{9}{|l|}{ Subjective Norms } & \\
\hline Negative & 70 & 70.7 & 29 & 29.3 & 99 & 100 & \multirow[t]{3}{*}{4.6} & $2.51-$ & \multirow{3}{*}{$<0.001$} \\
\hline Positive & 35 & 34.7 & 66 & 65.3 & 101 & 100 & & 8.26 & \\
\hline \multicolumn{8}{|l|}{$\begin{array}{l}\text { Perceived control } \\
\text { behavior }\end{array}$} & & \\
\hline Low & 71 & 78.0 & 20 & 22.0 & 91 & 100 & \multirow[t]{3}{*}{7.8} & $4.13-$ & \multirow[t]{3}{*}{$<0.001$} \\
\hline High & 34 & 31.2 & 75 & 68.8 & 109 & 100 & & 14.86 & \\
\hline \multicolumn{8}{|l|}{ Intention } & & \\
\hline Low & 59 & 67.0 & 29 & 33.0 & 88 & 100 & \multirow[t]{3}{*}{2.9} & $1.63-$ & \multirow[t]{3}{*}{$<0.001$} \\
\hline High & 46 & 41.1 & 66 & 58.9 & 112 & 100 & & 5.23 & \\
\hline \multicolumn{8}{|l|}{ Husband support } & & \\
\hline Weak & 84 & 78.5 & 23 & 21.5 & 107 & 100 & 12.5 & $6.41-$ & \multirow[t]{2}{*}{$<0.001$} \\
\hline Strong & 21 & 22.6 & 72 & 77.4 & 93 & 100 & 12.5 & 24.47 & \\
\hline
\end{tabular}


Journal of Maternal and Child Health (2018), 3(4): 252-260

https://doi.org/10.26911/thejmch.2018.03.04.02

Table 3. The results of multilevel logistic regression on IUD use determinants

\begin{tabular}{|c|c|c|c|c|}
\hline \multirow[b]{2}{*}{ Independent variable } & \multirow[b]{2}{*}{ b } & \multicolumn{2}{|c|}{$95 \% \mathrm{CI}$} & \multirow[b]{2}{*}{$\mathbf{p}$} \\
\hline & & $\begin{array}{c}\text { Lower } \\
\text { limit }\end{array}$ & $\begin{array}{c}\text { Upper } \\
\text { limit }\end{array}$ & \\
\hline \multicolumn{5}{|l|}{ Fixed Effect } \\
\hline Maternal education (high) & 4.06 & 0.68 & 7.44 & 0.019 \\
\hline Family income (high) & 3.90 & 1.67 & 7.64 & 0.041 \\
\hline Attitude (strong) & 4.54 & 0.52 & 8.55 & 0.027 \\
\hline Subjective norm (positive) & 3.06 & 0.01 & 6.10 & 0.049 \\
\hline Perceived behavior control (strong) & 3.40 & -0.04 & 6.85 & 0.053 \\
\hline Intention (strong) & 3.18 & -0.06 & 6.41 & 0.054 \\
\hline Husband support (strong) & 4.28 & 0.01 & 7.44 & 0.050 \\
\hline \multicolumn{5}{|l|}{ Random Effect } \\
\hline Posyandu & 1.56 & 0.88 & 27.48 & \\
\hline $\mathrm{N}$ observation $=200$ & & & & \\
\hline Log likelihood $=-28.73$ & & & & \\
\hline LR test vs. logistic regression, $\mathrm{p}=0.070$ & & & & \\
\hline $\mathrm{ICC}=32.10 \%$ & & & & \\
\hline
\end{tabular}

\section{The results of multilevel analysis}

Table 3 showed that high maternal education $(b=4.06 ; 95 \% \mathrm{CI}=0.68$ to 7.44 ; $\mathrm{p}=0.019)$, high family income $(\mathrm{b}=3.90$; $95 \% \mathrm{CI}=1.67$ to $7.64 ; \mathrm{p}=0.041)$, strong attitude $(\mathrm{b}=4.54 ; 95 \% \mathrm{CI}=0.52$ to $8.55 ; \mathrm{p}=$ 0.027), positive subjective norm $(b=3.06$; 95\% $\mathrm{CI}=0.01$ to $6.10 ; \mathrm{p}=0.049)$, strong perceived behavior control $(b=3.40 ; 95 \%$ $\mathrm{CI}=-0.04$ to $6.85 ; \mathrm{p}=0.053)$, strong intention $(b=3.18 ; 95 \% \mathrm{CI}=-0.06$ to $6.41 ; \mathrm{p}=$ $0.054)$, and strong husband support $(\mathrm{b}=$ 4.28; 95\% $\mathrm{CI}=0.01$ to $7.44 ; \mathrm{p}=0.050$ ) were positively associated with IUD use among women at reproductive age.

Posyandu had a strong contextual effect on IUD use with $\mathrm{ICC}=32.10 \%$. This number was greater than the standard of role of thumb size which was 8-10\%, then the contextual effect was important to be noted.

\section{DISCUSSIONS}

\section{The effect of education and IUD use}

The result of the study showed that there was a significant effect between maternal education and the use of IUD. Mother with high education level were more likely to use
IUD. In this study, 75 women (78.1\%) with higher education were using IUD.

Hong et al. (2015) explained that there was a significant relationship between education and theuse of Intra-uterine Contraception. High level of maternal education would increase the maternal knowledge in the selection of contraception which was appropriate for them. This was because a highly-educated person would be more knowledgeable and more receptive to information, including the importance of participation in the selection of contraceptives.

A low-educated person would take decisions correctly because of the knowledge gained from magazines, books, television or others. The low use of IUD contraception was due to the acceptors' ignorance about the advantages of the method (Yustiani et al., 2013). Acceptors' ignorance about the advantages of IUD contraceptive method was due to low education and lack of information about contraceptive given by health personnel (Dehlendorf et al., 2013). 


\section{The effect of family income on IUD use}

The result of the study showed that there was a significant effect between family income and IUD use. Women at reproductive age who have high family income were more likely to use IUD.

Ela et al. (2016) explained that family income was one of the factors that affect the use of IUD. Women with high family income levels tend to choose more effective contraceptives, because sufficient income motivated someone to choose a better contraceptive.

Hong et al. (2015) stated that socioeconomic and educational factors also affected women's knowledge in determining the type of contraception, women who have sufficient income and higher education would have high knowledge and easiness in choosing the appropriate type of contraception compared to women who have low income. There were disadvantages, advantages, and also side effects of each instrument in contraception type.

Rational choice of contraception was essentially a voluntary choice of clients without any compulsion, based on rational considerations from the point of view or technical use, medical health conditions, and income from each partner, therefore, the family income level also affected the selection of contraceptives, especially IUD that required higher cost than other contraceptives (Liando et al., 2013).

\section{The effect of attitude on IUD use}

The success of the family planning program was determined by the knowledge, attitudes, and culture. So, that the acceptors know about the information of contraception, both advantages and disadvantages of using the contraceptive.

Factors that affect the use of IUD were the level of maternal knowledge and other supporting factors (Hall et al., 2012).
A positive attitude about the IUD was affected by good knowledge. Better knowledge increased the likelihood of IUD use (Arma et al., 2014). Knowledge about the types of contraceptive method, side effects, contraindication, benefit, and deficiency was necessary so that contraceptive users could use the contraceptives based on rational, effective, and efficient (Gomez et al., 2014).

Alemayehu et al. (2012) stated that mothers with higher knowledge were 2 times more likely to have positive attitude toward IUD sue compared to mothers with lack of knowledge.

\section{The effect of subjective norms on IUD use}

The result of the study showed that there was a significant effect between subjective norm and the use of IUD. Subjective norms factor could affect the clients in choosing contraceptive methods. These factors include misconceptions about various methods, religious beliefs, and also the levels of education and perceptions about the risks of pregnancy and the women's status(Tyler et al., 2012).

Generally, women at reproductive age prefer to follow the subjective norms rather than choosing contraceptives that have been explained by health personnel, such as midwives. Various factors must also be considered including health status, side effects, potential, consequences of failure/ unwanted pregnancies, desired/ planned family member, approval of partners, and even high integral of environmental culture norms in FP services (Frost et al., 2012). Other reason related to the social conditions of the selection was the high costs (Hall et al., 2015).

\section{The effect of perceived behavior control on IUD use.}

The result of the study showed that there was a significant effect between perceived 
behavior control and the use of IUD. Mothers with high perceived behavior control were more likely to use IUD. In this study, there were 75 women $(78.1 \%)$ out of 109 women at reproductive age with a high perceived behavior control who used IUD. High perceived behavior control was one of the factors that affect the use of IUD.

Joeliatin et al. (2016), stated that perception was a process that arised due to the activity (service received) that can be felt by an object. Because each person's perception of an object (service) was different.

The low perception of IUD use has an impact on the low willingness to use IUD, therefore, a strong factor that affected the high perception was expected to increase the use of IUD (Komey, 2016).

\section{The effect of intention on IUD use}

The result of the study showed that there was a significant effect between intention and the use of IUD. Women at reproductive age who have high intention were more likely to use IUD. In this study, 66 women (58.9\%) out of 112 women at reproductive age with high intention were using IUD.

Intention was the level of certainty about behavioral practices. Intention was determined by subjective attitudes and norms. Frost et al. (2012) explained that with the high intentions and changes in behavioral perceptions in using IUD, the likelihood of using IUD would be greater compared to women with low intention.

Higgins et al. (2014) also stated that with the support of the environment especially the support of husbands, it could increase the intention of women at reproductive age to use IUD.

\section{The effect of husband support on IUD use}

The result of the study showed that there was a significant effect between husband support and the use of IUD.
Salisbury et al. (2016) stated that factors that influenced the use of IUD were partners, health, and contraceptive methods.

A study by Alemayehu et al. (2012) also showed that husband's support influenced the selection of contraception. The family became a party that was able to introduce and encourage women to use contraception because of the emotional bond and beliefs within the family.

The role of the family was no more real than the one given by the surrounding environment because it provided prereflection experience. Support from the husband in the use of contraception was necessary because without the husband support, feeling of comfort in using the contraception would not be obtained. Contraceptive methods can not be forced, the couples must choose the best method of contraception, cooperation in use, finance contraceptive spending, and pay much attention to signs and dangers in the use of the contraception (Higgins et al., 2014).

Based on the result of the study, it can be concluded that there high maternal education, high family income, strong attitude, positive subjective norm, high perceived behavior control, high intention, and strong husband support increased the likelihood of IUD use. Posyandu has a contextual effect on IUD use.

\begin{tabular}{c}
\hline REFERENCE \\
\hline Alemayehu M, Belachew B, Tilahun T \\
(2012). Factors Associated with \\
Utilization of Long Acting and Per- \\
manent Contraceptive Methods \\
among Married Women of Repro- \\
ductive Age in Mekelle Town, Tigray \\
Region, North Ethiopia. BMC Preg- \\
nancy and Childbirth, 12: 6. \\
ArmaF, Tanjung A, Maisa ZI, Arifin M, \\
Novera M (2014). Faktor-Faktor yang
\end{tabular}


Berhubungan dengan Pemilihan Kontrasepsi IUD Bagi Akseptor KB Di Wilayah Kerja Puskesmas Sungai Lansek Tahun 2014. Jurnal Kesehatan.

Badan Pusat Statistik (2016). Statistik Indonesia 2016. Jakarta: BPS.

BKKBN (2017). Rencana Strategis badan Kependudukan dan Keluarga Berencana Nasional Tahun 2015-2019. Jakarta.

Budiarti I, Nuryani DD, Hidayat R (2017). Determinan Penggunaan Metode Kontrasepsi Jangka Panjang (MKJP) Pada Akseptor KB. Jurnal Kesehatan, 8 (2): 220-224.

Dehlendorf C, Levy K, Kelley A, Grumbach K, Steinauer J (2013). Women's Preferences for Contraceptive Counseling and Decision Making.Contraception, 88:250-256.

Ela S, Hall KS, Melissa K. ZochowskiMBA. (2016). I Don't Know Enough to Feel Comfortable using Them:" Women's Knowledge of and Perceived Barriers to Long Acting Reversible Contraceptives on a College Campus. Contraception, 93(6): 556-564. doi:10.1016/j.contraception.2016.02.007.

Frost JJ, Lindberg LD, Finer LB (2012). Young Adults' Contraceptive Knowledge, Norms and Attitudes: Associations with Risk of Unintended Pregnancy. Persp Sex Reprod Health, 44(2):107-116.

Glasier A, Gebbie A (2012). Metode Barier dalam Keluarga Berencana dan Kesehatan Reproduksi. Jakarta: EGC.

Gomez AM, Fuentes L, Allina A. (2014). Women or LARC first?. Reproductive autonomy and the promotion of longacting reversible contraceptive methods. Perspect Sex Reprod Health, 46(3):171-5.
Hall KS, Patton E, Crissman H, Zochowski M, Dalton VK. (2015). A PopulationBased Study of U.S. Women's Preferred Versus Usual Sources of Reproductive Health Care. Am J Obstet Gynecol.

Hall KS, Moreau C, Trussell J. (2012). Continuing social disparities despite upward trends in sexual and reproductive health service use among young women in the United States. Contraception, 86: 681-686.

Higgins JA (2014). Celebration meets caution: LARC's boons, potential busts, and the benefits of a reproductive justice approach. Contraception, 89(4): 237-41.

Hong R, Montana L, Mishra V (2015). Family Planning Services Quality as a Determinant of Use of IUD in Egypt. BMC Health Services Research, 6:79.

Joeliatin, Murti B, Suryani N (2016). Theory of Planned Behavior on the Determinants of Participation in the Long-Term Contraceptive Method Among Women of Reproductive Age, in Nganjuk, East Java.Journal of Health Promotion and Behavior, 1(3): 171-179 https://doi.org/10.26911/thejhpb.2016.01.03.04.

Kemenkes RI (2016). Situasi dan Analisis Keluarga Berencana. Jakarta: Pusat data dan Informasi Kementerian Kesehatan Republik Indonesia.

Komey L (2016). Knowledge, Attitude and Perceptions of Contraceptive Use Among Second Cycle Institutions in the Adentan Municipality. University of Ghana.

Liando, Runkat M, Manueke I (2013). Faktor-Faktor yang Berhubungan dengan Penggunaan Alat Kontrasepsi Dalam Rahim di Kelurahan Pangolombian Kota TomohonTahun 2013. JurnalIlmiahBidan, 2(1). 
Journal of Maternal and Child Health (2018), 3(4): 252-260

https://doi.org/10.26911/thejmch.2018.03.04.02

Tyler CP, et al. (2012). Health Care Provider Attitudes and Practices Related to Intrauterine Devices for Nulliparous Women. Obstet Gynecol. 119(4): 762-71.

Salisbury P, Hall L, Kulkus S, Paw MK, Tun NW, Min AM, Chotivanich $\mathrm{K}$ et al. (2016). Family Planning Knowledge, Attitudes and Practices in Refugee and Migrant Pregnant and Post-
Partum Women on the ThailandMyanmar Border - a Mixed Methods Study. Reproductive Health: 13: 94. Yustiani (2013). Hubungan Tingkat Pendidikan Ibu Rumah Tangga dengan Persepsi Penggunaan Alat Kontrasepsi di Kelurahan Tondo Kecamatan Mantikulore Kota Palu. 